\title{
Listening comprehension and strategy use: a longitudinal exploration
}

Article

Accepted Version

Graham, S., Santos, D. and Vanderplank, R. (2008) Listening comprehension and strategy use: a longitudinal exploration. System, 36 (1). pp. 52-68. ISSN 0346-251X doi:

https://doi.org/10.1016/j.system.2007.11.001 Available at https://centaur.reading.ac.uk/12567/

It is advisable to refer to the publisher's version if you intend to cite from the work. See Guidance on citing.

To link to this article DOI: http://dx.doi.org/10.1016/j.system.2007.11.001

Publisher: Elsevier

All outputs in CentAUR are protected by Intellectual Property Rights law, including copyright law. Copyright and IPR is retained by the creators or other copyright holders. Terms and conditions for use of this material are defined in the End User Agreement.

\section{www.reading.ac.uk/centaur}

\section{CentAUR}

Central Archive at the University of Reading

Reading's research outputs online 
Listening comprehension and strategy use: a longitudinal exploration.

Suzanne Graham ${ }^{\text {a, * }}$, Denise Santos ${ }^{\text {b, } 1}$, Robert Vanderplank ${ }^{\text {c, } 2}$ 


\section{Abstract}

This paper examines the development of strategy use over six months in two lower-intermediate learners of L2 French in secondary schools in England. These learners were selected from a larger sample on the basis of their scores on a recall protocol completed after listening to short passages at two time points: one was consistently a high scorer; the other one, a low scorer. Qualitative data on these two learners' strategic behaviour were gathered at the two time points from verbal reports made by learners while they were completing a multiple choice listening task. Our results show a high degree of stability of strategy use over the time period, with preexisting differences between the high and low scorer persisting. The theoretical and pedagogical implications of these findings are discussed.

Key words: Listening comprehension; Learner strategies; French as a foreign language; Verbal report

\section{Introduction}

Despite the wide range of areas investigated in listening strategy research (see Macaro, Graham and Vanderplank, 2007), there is a lack of research looking specifically at how listening strategy use develops or changes over time in the absence of explicit strategy training. An understanding of this pattern of development would seem vital for the planning of listening strategy instruction in particular, and for the teaching of listening in general. Furthermore, in order to make an informed decision about whether 
strategy instruction is necessary for learners to acquire effective strategies, we need evidence regarding the form strategy development takes in the absence of any explicit instruction.

\section{Background}

Studies that do touch upon strategy development have taken one of three approaches: (1) comparing cross-sectionally the strategy use of learners at different levels of proficiency; (2) identifying development within the framework of a programme of strategy instruction; and (3) tracing strategy development over time for a single cohort of learners.

The first of these perspectives is exemplified by studies by Vandergrift (e.g. Vandergrift 1997, 1998) which highlight differences in strategy use by Novice and Intermediate learners of French. Using data elicited through think-aloud protocols, Vandergrift claims that Intermediate listeners use a higher percentage of metacognitive strategies than do Novice listeners (Vandergrift, 1997) - metacognitive strategies being "higher order executive skills", such as planning, monitoring and evaluation of learning (O’Malley and Chamot, 1990: 44). Subjects' inferencing and elaboration strategies, where non-linguistic or contextual knowledge is used to expand upon or interpret textual information, lead Vandergrift to conclude that novice-level learners, who are linguistically weak, tend to rely on prior knowledge (e.g. schematic knowledge, knowledge of the text's subject matter, world knowledge), while intermediate-level students, with their larger linguistic base and therefore larger information processing capacity are able to use more metacognitive strategies (Vandergrift, 1998). 
Vogely (1995), investigating differences in reported strategy use and judgements of effective strategies among university learners of Spanish, also found that linguistic proficiency seems to influence strategy use. Data were elicited through a questionnaire completed after three listening tasks. Only one statistically significant difference emerged between students at different course levels in terms of reported 'effective' strategy use, with beginning learners more concerned about understanding individual unknown vocabulary items, a tendency which Vogely attributes to learners' narrower linguistic base and hence a greater preoccupation with individual words.

Although these cross-sectional studies appear to highlight differences in strategy use at different levels, they offer few insights into how strategy use changes or develops in individual learners over time. The qualitative examples in Vandergrift (1998) indicate that strategy use is usually highly individualised, even within one proficiency band. This suggests that research might identify very different patterns of strategy development between learners. Furthermore, it is unclear whether learners develop different strategies over time, or whether they become more efficient at marshalling them to deal with difficulties. The second of these two interpretations is supported by research (e.g. Vann and Abraham, 1990) that suggests that effective and less effective learners use similar strategies but differ in how they use them. It is therefore of interest not simply to compare learners over time but to compare learners from different proficiency bands over time.

Some studies concerned with the second research perspective, the effects of strategy training, investigate listening strategy development incidentally. Few clear insights emerge, however, with strategy instruction seeming to make little impact on strategy use over time, even in cases where it brings about improvements in learners' 
listening comprehension performance (McGruddy, 1995; Seo, 2000). A dissenting voice is Ozeki (2000), who, studying the effects of strategy instruction to EFL first-year college students in Japan, reports that while the control group changed little in the strategies they claimed to use at the start and end of the study, the treatment group showed a number of changes, particularly with regard to note-taking (which had been practised extensively).

Unfortunately, there were some shortcomings in Ozeki's data collection procedures, such as gathering interview data on strategy use only at pre-test (alongside a pre- and post-test questionnaire). In the other intervention studies mentioned there was a similar weakness - a failure to use the same fine-grained method of strategy elicitation at both pre- and post-test. The only instrument used at both pre and post-test by McGruddy to elicit data on strategy use, and hence allow insights into changes over the period of the intervention, was a questionnaire, which McGruddy admits may have not have been as valid as verbal report. In Seo's study, a questionnaire on strategy use was administered only at post-test, so that we have no information about how strategy use changed for either the experimental or comparison groups. Both McGruddy and Seo also seem to try to infer strategy use through subjects' performance on test items, an approach which seems questionable given the complex nature of strategies.

In terms of the third research perspective on strategy development, we have identified just one study, Peters (1999), that adopts a longitudinal perspective without an intervention. This study investigated the listening strategies of eight pupils in the 'Bain Linguistique' (intensive French) class of Year 5 in a primary school in Ottawa over a school year, in order to ascertain what changes occurred in strategy use among more and less proficient pupils. 
Between October and May, monthly think-aloud interviews were conducted in order to gather data on pupils' strategy use and to show which strategies led to successful listening comprehension. Overall, there appears to have been little change in the frequency of strategy use among the eight subjects from the first stage (Oct-Jan) to the second stage (Feb-May), although the frequency of strategies used by the less proficient group was actually lower in the second stage than the first.

However, the results did show a significant change in the use of inferencing strategies across the two stages. Use of such strategies decreased for both proficiency groups, but especially for the less proficient group and in particular inferencing strategies, including linguistic inferencing (defined as guessing on the basis of a known word or words), personal elaboration (personal knowledge and experience) and creative elaboration (inventing a story).

In terms of metacognitive strategy use, 'plannification' (the French term used by Peters) was used less often by both groups in the later part of the year. 'Plannification' is a group of strategies including selective and general attention (the latter meaning that listeners decide to give their full attention to the listening task-Vandergrift, 1997: 392). Peters argues that these strategies had become automatic by the second phase and that they were no longer controlled processes, from which one might infer that they were no longer accessible to report.

While Peters' study does present a more systematic tracing of strategy development, using a single, more fine-grained, task-based strategy elicitation method at each stage in the form of think-aloud interviews, the method of analysis obscures certain aspects of the subjects' strategy development. Instances of strategy use for each group of learners were simply totalled and totals for the first stage compared with those for the 
second stage. This approach does not provide a clear picture of individual deployment of particular strategies. Moreover, apparent changes in the total strategy use of each proficiency group may be attributable to perhaps just one or two learners.

The above review suggests, on the one hand, that we have insufficient evidence about how strategies develop or how their use changes for us to draw firm conclusions. In addition, the methodological shortcomings of the studies mean that the limited data available are not totally reliable. Furthermore, none of the studies addresses fully the issue of task specificity of strategy use, i.e. that strategies employed by listeners will in part depend on the demands made by the listening task (Chamot, 2004).

On the other hand, there are certain patterns regarding strategy development that are detectable across the few studies that do exist. First, that inferencing and reliance on prior knowledge seem to decline over time (perhaps as learners' linguistic base increases), and second, that the use of metacognitive strategies increases, though this may be limited to more 'able' learners and may be linked to the availability of processing capacity (which in turn may be related to linguistic knowledge). Hence strategy development seems in some way to be related to proficiency issues.

\section{The present study}

The present study sought to explore the relationship between learners' listening proficiency and strategic behaviour and to map out how this relationship develops over time when there is no explicit strategy training. Specifically, we address the following question: How does strategy use develop over time in students who score differently on a listening test? 
The methodological issues highlighted above suggest the need for a longitudinal study that uses introspective measures at pre- and post-test, in order to provide valid data on strategy development over time. While the reliability of self-report data has been questioned (for example, by Seliger, 1983: 184-189), there is general agreement in the literature that it is the best elicitation method available for gaining insights into on-line strategy use (Vandergrift, 2003), provided care is taken in its implementation and analysis. Important issues concern whether the act of verbalisation disrupts the process of listening, especially if the researcher not the listener pauses the tape, and if excessive prompts are given for verbalisation, and whether subjects can in fact remember the strategies they have used (see Bacon, 1992; Macaro et al., 2007). Measures were taken in the present study to minimise these problems (see below).

Also required is an approach to analysis that takes into consideration the problems posed by different listening tasks and the strategies used to deal with these problems. This is the approach adopted in the present study. Further details are given below.

\subsection{Research design}

The study involved collecting data on participants' listening proficiency and then collecting data through verbal self-reports on the strategies used by these participants when answering multiple choice questions on a French listening comprehension passage. Data on both listening proficiency and strategies were collected at two time points, October and April, six months apart. 
It was decided to take a case study approach to the data to reflect our belief that it is less the number or type of strategies used that leads to more or less effective listening, but rather the manner in which they are employed (see also Vann and Abraham, 1990: 189-191). Specifically, a case study enabled us to explore in depth how strategies were employed in relation to different demands made by the listening tasks with which participants were faced.

\subsection{Participants}

Two students out of a group of fifteen from three schools in England are the focus of the present study. All fifteen were preparing for a lower-intermediate examination, the Advanced Subsidiary (AS) examination, at age 17 and had been studying French for five to six years. Immediately prior to the AS course, they had gained one of the top three grades in French for the examination taken at age 16, the General Certificate of Education (GCSE). On average, students received four to five hours of French instruction per week during the AS course, with listening occupying approximately a quarter of this time or less.

\subsection{Listening proficiency: Recall protocols}

Subjects' listening proficiency was assessed at Time 1 (October) and Time 2 (April) using two different audio-recordings of comparable difficulty on the topic of holidays. Each of these recordings involved four different conversations between two people, and students were asked to listen to each of these conversations twice and to 
individually write down in English (L1) everything that they thought they had understood. Thus they were being asked to write more than a summary of the text. While the problems in finding a completely valid and reliable way of assessing listening proficiency are widely acknowledged (Alderson and Banerjee, 2002), the recall protocol appears to provide a more complete assessment of listeners' understanding (see Berkemeyer, 1989: 131, in relation to the use of recall protocols in reading). Each individual passage was kept short to ensure that the recall protocol was not a memory test.

At each time point, recall protocols were scored by two raters independently, using a rating score which assessed the number of idea units recalled, whether these were words or phrases, to give a score per passage for each learner and a total score. A paired sample t-test on total scores showed no significant difference between the two raters $($ Time $1, \mathrm{t}=.00, \mathrm{df}=29, \mathrm{p}=1.00 ;$ Pearson's correlation coefficient $=0.950$; Time $2, \mathrm{t}=1.491, \mathrm{df}=28, \mathrm{p}=.147 ;$ Pearson's correlation coefficient $=.957)$. Differences in scores were then resolved by discussion, at both time points.

Total scores were then used to rank learners at both times and to group them into two listening proficiency group, top (above the mean) and bottom (below the mean). On the basis of this grading, two participants were selected who form the focus of the present case study. The learners were chosen because their listening proficiency remained fairly stable across the two time points. One student, $\operatorname{Alan}^{1}$, was in the upper proficiency group at Times 1 and 2 , while Sue ${ }^{1}$ was in the bottom group on each occasion. In addition, it was considered to be important to compare two students who did not differ greatly in terms of their demonstrated linguistic knowledge since such knowledge is a likely variable in strategy use (see Macaro et al., 2007). Both Sue and 
Alan displayed similarly high levels of linguistic knowledge as assessed by a vocabulary and grammar test also used in the wider study (see Santos, Graham and Vanderplank, under review, for further details).

\subsection{Strategy elicitation: Verbal reports}

Two recordings from a familiar topic (a 'disaster') were selected for a strategy elicitation task. The entire group of 15 students participated in the exercise, though we report here only the evidence elicited from our two chosen participants.

The passages chosen were of comparable difficulty in terms of length, words per

minute, percentage of unknown vocabulary ${ }^{2}$ and genre (both passages were radio broadcasts and were taken from teaching materials used with students of AS level). At Time 1, students listened to a passage about floods (Authentik en français, 2001) and at Time 2 to a passage about an accident in the Alps (Corless, Corless and Gaskell, 1990). Comprehension of the recordings was tested by a number of multiple-choice questions, a format chosen for its familiarity to participants (thus making verbalisation more straightforward) and because the short nature of the questions would minimise the risk of participants forgetting how they had processed information. The questions were composed in English to avoid difficulties from misunderstanding the written word in French. Some focused on 'local' details, others required a more global understanding. Of course, the multiple-choice question format is likely to pose specific problems to listeners and thus to prompt specific strategies, which may or may not be similar to those found in more 'authentic' and interactional listening tasks. However, in creating tasks that posed questions similar to those which students would have faced in their class 
work, we were aiming for the "authentic" context for our study that White, Schramm and Chamot (2007: 103) recommend for strategy research.

The students were reassured that they were not taking a test and that the researchers were primarily interested in how they listened in French. They were instructed to approach the task as they wished and were given full control of the tape recorder, being able to pause the tape and rewind it as often as they wanted. At the same time, they were asked to keep the interviewer informed of how they were understanding the tape and answering the questions. This approach was chosen because it was felt that allowing participants to select the moment at which they verbalise their thoughts should mean that these thoughts are captured more immediately (cf. Laviosa, 2000), and would interrupt the normal process of listening less than if the researcher chose where to pause the tape. We are aware that such an approach has its own shortcomings. In particular, by asking students to rewind the tape, we were approaching the listening task as an instructional event and not as an everyday interaction involving listening in a foreign language. However, we believe that our choice allowed us to gain insight into listeners' perceived difficulties and therefore it is more likely to inform principled decisionmaking in listening pedagogy. Students' verbalisations were tape-recorded with their permission.

\subsection{A framework for the study}

The verbal reports were transcribed verbatim. Two researchers made a preliminary qualitative analysis for the entire group, focusing on instances of strategy 
use and the general approach of each learner. From this initial analysis, a taxonomy of strategies employed by the group was drawn up (Figure 1) which will serve as a framework for the present study. Definitions were developed for strategies emerging from the data that were felt to be missing from established taxonomies (O'Malley and Chamot, 1990; Vandergrift, 2003), although definitions were also used from these taxonomies where appropriate.

$<$ Figure 1 here >

Using the taxonomy thus created, the transcripts were coded independently by two researchers. Based on an analysis of the coding of two-thirds (9) of the Time 1 transcripts, inter-rater reliability was calculated as $85 \%$. Differences in coding were resolved by discussion.

A second step was to make a comparison between the multiple-choice questions for each passage in terms of the problems they potentially posed to listeners. On the basis of this, we were able to form pairs of questions, one from the first task and one from the second, which placed similar demands upon the participants. This enabled us to compare strategies across the two time points, on the assumption that similar question types would be likely to give rise to similar strategic behaviour. Table 1 illustrates these pairings.

<Table 1 here> 


\section{Data analysis}

The following analysis compares the two students both cross-sectionally and longitudinally, using the question pairs identified above. Each piece of data cites the relevant part of the recording, with key aspects highlighted in bold type. It also gives the multiple-choice options. The correct answer to each question is underlined. The analysis of question pairs $\mathrm{B}$ and $\mathrm{C}$ has been combined, as both pairs made similar demands on participants.

\section{Pair A}

\begin{tabular}{|c|c|}
\hline Time 1 & Time 2 \\
\hline $\begin{array}{l}\text { Ce qu'ont vécu ce week-end les } \\
\text { départements de l'Aude, du Tarn, et des } \\
\text { Pyrénées orientales, la France ne l'avait } \\
\text { pas connu depuis 1940! Ce type } \\
\text { d'inondation n'arrive qu'une ou deux } \\
\text { fois par siècle. En deux jours il est tombé } \\
\text { jusqu'à } 500 \text { litres d'eau par mètre carré } \\
\text { à certains endroits. C'est presque } \\
\text { l'équivalent d'un an de pluie dans cette } \\
\text { région. }\end{array}$ & $\begin{array}{l}\text { Ah oui, la journée a été tragique dans les } \\
\text { Alpes hier. Douze alpinistes sont morts, } \\
\text { et il y a des blessés, le drame de la Tour } \\
\text { Ronde ayant été le plus cruel dans le } \\
\text { massif du Mont Blanc. Une cordée } \\
\text { d'alpinistes britanniques s'est décrochée } \\
\text { et, en tombant dans le vide, elle a } \\
\text { bousculé les cordées situées plus bas, qui } \\
\text { sont tombées à leur tour, les unes après } \\
\text { les autres. }\end{array}$ \\
\hline $\begin{array}{l}\text { 1. Three French departments have } \\
\text { been hit by: }\end{array}$ & $\begin{array}{l}\text { 1. The passage reports: } \\
\text { a) On a demonstration blocking roads }\end{array}$ \\
\hline $\begin{array}{l}\text { a) Strikes } \\
\text { b) Riots }\end{array}$ & $\begin{array}{l}\text { b) On a journey to Mont Blanc by British } \\
\text { tourists }\end{array}$ \\
\hline c) Floods & c) On an accident in the mountains \\
\hline d) Snow storms & d) On blessing a tower in the Alps \\
\hline
\end{tabular}


Before the first question of both passages, students were expected to comment on how they would tackle the task as a whole. This was the case for Sue. On the surface, she took what appeared to be a more careful approach at both time points than Alan. At Time 1, she tried to predict possible answers to questions before listening, although she claimed to be unable to do so, and then predicted likely vocabulary that she might hear. Having predicted this vocabulary, she decided to selectively attend to these items, as she put it, to be on the lookout, hear out for those particular words. Her pre-listening strategies at Time 2 took a similar form - prediction of vocabulary, the writing of visual prompts (ranging from the more difficult - plus que un heure (sic) $<>$ more than an hour - to some very basic vocabulary - douze <> 12). Her exchange with the researcher outlines how she dealt with the task as a whole: Interviewer: So you have looked at all the questions, all the answers and you have written down things here and there and just to listen out for them?

Sue: Yes, to see if there's any, if there is a word and I go 'oh, OK, so that could be that one'...

At Time 1 this approach was very focused on individual items of lexis, and seemed inadequate to compensate for Sue's difficulty in segmenting what she heard and in identifying known words. Problems with determining sense groupings are suggested by the way in which she paused the tape in the middle of the central word inondation (flood, second sentence, see above). At Time 2, there was some evidence of Sue taking a more global view of the text, in that she played the passage all the way through at the start. However, at both times hypothesis formation was strongly linked with deduction 
based on negative evidence, i.e. on what she had not heard, on what she vaguely thought she had heard, or on what she did not know, as the following comments suggest:

\begin{tabular}{|l|l|}
\hline \multicolumn{1}{|c|}{ Time 1 } & \multicolumn{1}{|c|}{ Time 2 } \\
\hline There was no (...) words I recognised & I thought I had heard 'blessing', I \\
[...] Which suggests that it could be 'a' & realised it wasn't, it was, I can remember \\
[strikes] or 'b' [riots], because those are & what it is, something like injury I think in \\
the two words that I probably don't know & French, so I knew it wasn't that...so I am \\
in French. & guessing... \\
&
\end{tabular}

Alan

Alan, by contrast, undertook no preparation before commencing the task at either time point, with no prediction of lexis, themes or answers, or evidence of selective attention prior to listening. Like Sue at Time 1, he did not listen to the passage all the way through, yet in listening beyond the opening lines of both texts, he quickly identified the theme of both passages. Thus, even though he sometimes approached questions on a one-by-one basis, he quickly established an understanding of 'what the passage is about' which seemed to compensate for a fragmentary approach which might have been less helpful for other students. At Time 1, he confidently identified the word for water, elaborating from that word that It's got to be floods. Thus any 'selective attention' on his part occurred after gaining an overall understanding, not before, and seemed to have become an automatised form of the strategy. Although seemingly sure 
about his initial hypothesis, he also showed an awareness that later information in a passage might contradict an original hypothesis and double checked his answer, not by listening to parts of the passage already heard, but to later information. At Time 2, after identifying the word Alpes, he correctly inferred that the passage was about an accident in the mountains, by integrating information from later in the passage. He also monitored his hypothesis to see if it fitted in with the passage as a whole, by using information in a later question (Question 4, The police who came to the scene...) and checking whether this interpretation was plausible.

\section{Pairs B and C}

\begin{tabular}{|c|c|}
\hline Time 1 & Time 2 \\
\hline $\begin{array}{l}\text { Ce qu'ont vécu ce week-end les } \\
\text { départements de l'Aude, du Tarn, et des } \\
\text { Pyrénées orientales, la France ne l'avait } \\
\text { pas connu depuis 1940! Ce type } \\
\text { d'inondation n'arrive qu'une ou deux } \\
\text { fois par siècle. [...] C'est presque } \\
\text { l'équivalent d'un an de pluie dans cette } \\
\text { région. Alors, bien sûr, tous les secteurs } \\
\text { sinistrés vont avoir, euh, du mal à s'en } \\
\text { remettre car les dégâts sont énormes et le } \\
\text { bilan humain est déjà très lourd, donc: } 26 \\
\text { morts et au moins } 3 \text { disparus. }\end{array}$ & $\begin{array}{l}\text { Ah oui, la journée a été tragique dans les } \\
\text { Alpes hier. Douze alpinistes sont morts, } \\
\text { et il y a des blessés, le drame de la Tour } \\
\text { Ronde ayant été le plus cruel dans le } \\
\text { massif du Mont Blanc [...]. En moins } \\
\text { d'une heure, des gendarmes de haute } \\
\text { montagne sont arrivés de Chamonix en } \\
\text { hélicoptère. Ils ont été aidés par des } \\
\text { bénévoles sur place. On a retrouvé les } \\
\text { victimes dans une crevasse, et il a fallu } \\
\text { que les sauveteurs fassent vite pour } \\
\text { dégager les survivants, dont une femme } \\
\text { restée suspendue dans la crevasse par } \\
\text { son sac. Certains étaient morts des suites } \\
\text { de la chute, avec des fractures, d'autres } \\
\text { ont été étouffés par la neige. Ils avaient } \\
\text { fait une chute de } 400 \text { mètres.... }\end{array}$ \\
\hline $\begin{array}{l}\text { 3. This type of disaster usually } \\
\text { happens: }\end{array}$ & 3. Help arrived: \\
\hline a) Once or twice every hundred years & a) Too late to save anyone \\
\hline b) Only in the winter & b) More than an hour later \\
\hline c) Yearly & c) Straight away \\
\hline
\end{tabular}


d) Every couple of years

\section{The number of people killed or missing runs to at least:}

a) 3

b) 29

c) 26

d) 500 d) Less than an hour later

\section{The number of people who died was:}

a) One woman

b) In the hundreds

c) 12

d) 400

Sue

Sue made her first response to Time 1 Question 3 without articulating how she arrived at an answer. She then announced that the passage was hard and that she was going to predict some vocabulary and write down some visual prompts, which she did for numbers and certain words, hundred/cent; winter/hiver; 3/trois. After listening again she seemed to double check her answer, announcing that she intended to change her response from the correct answer (a) to every couple of years. However, her doublecheck monitoring again involved her using a degree of negative deduction: cos it definitely wasn't one of any of the middle two. Her rejection of the right answer seems to be based on her not hearing an item she predicted, wrote down and selectively attended to: Hum... Thinking about it, actually, hum (...) I didn't hear 'cent', so, that's what I'm thinking: it's not here.

Similarly, for Time 1 Question 4, Sue claimed that numbers were what she struggled with and that if she could selectively attend to those first of all, she would then 
be able to turn to the rest of the text. Selective attention, however, took a very narrow form, in which Sue was content with an apparent match between an item she heard and one of the options, seemingly unaware of other numbers that followed in the text, or of the fact that the question asked for the number of people killed or missing: 'Yes, I heard 'vingt-six morts'. So, twenty-six dead, I think, so it's probably that one.

At Time 2, prediction, visual prompts and selective attention were employed for both Questions 3 and 5. For the former, Sue commented that she might have heard less than an hour and gendarmes (police), which also appeared in the options and question and thus suggested that d) was the correct answer. However, she then seemed to acknowledge her lack of further comprehension of the relevant section of the passage, explaining But I don't know if that helps or not. Thus, comprehension monitoring was not followed by any remedial action and the question was simply abandoned. As Table 1 indicates, Question 5 posed additional challenges in that the key information appeared at the start of the passage, not the end. The presence of numbers in the closing lines of the Time 2 passage was an additional distraction, making it all the more important for students to understand what was said at phrase level. To a greater extent than at Time 1, Sue did show some such understanding when she rejected une femme (one woman) as the answer, saying that I heard something about one woman but I think it was not the fact that that she was the only one. However, she still seemed to rely mainly on negative evidence and on identifying matching lexical items in choosing her final answer. She commented I didn't hear anything about 12 and that she was wavering between options b) and d) after hearing cent (hundred) in the phrase 400 mètres towards the end of the passage. 
Alan

How Alan arrived at the correct answer for Question 3 at Time 1 was unclear, although he did seem able to identify with confidence the part of the passage containing all the key information. This was true too for Question 4 Time 1. He firstly identified each separate element, vocalising what he heard on a phrase level:

Hum, vingt-six morts! Voilà numéro quatre! Il a dit 'vingt-six morts et trois...' and three people missing.

Having established that he understood what he heard (comprehension monitoring), he then checked what the question required, integrating different pieces of information, questioning himself and comparing what he had heard with the question: So, do I take it twice? Or, do I add it up? (reading from the sheet) 'The number of people killed or missing amounts to...' Of course, when you add up the numbers, it's going to be twenty-nine.

Confidence in locating the key information was also apparent in Alan's performance at Time 2, where he reproduced vocally (if approximately) the two central phrases les gendarmes arrivés (sic) and moins d'une heure. He showed no desire to check this interpretation by rewinding, which may indicate a degree of over-confidence at this stage. However, when he was uncertain, checking did occur through listening again, as was the case with Question 5 Time 2. He coped without difficulty with the fact that this question was out of order, after hearing the opening lines. He claimed to have initially heard the number deux but on a subsequent listening to have checked his understanding: then I figured, then I remembered it didn't actually say 'deux' it said 'douze'. 


\section{Pair D}

\begin{tabular}{|l|}
\hline Time $\mathbf{1}$ \\
\hline C'est le département de l'Aude qui a \\
payé le plus lourd tribu à ce phénomène \\
exceptionnel: $\mathbf{5 0 0}$ personnes ont dû être \\
hélitreuillées hier, et ce matin deux \\
villages sont encore totalement isolés. \\
\hline
\end{tabular}

5. 500 people were carried to safety by:

a) Volunteers

b) Helicopter

c) Ambulance

d) Boat

\section{Time 2}

En moins d'une heure, des gendarmes de haute montagne sont arrivés de Chamonix en hélicoptère. Ils ont été aidés par des bénévoles sur place. On a retrouvé les victimes dans une crevasse...

4. The police who came to the scene:

a) Found no survivors

b) Were helped by people at the scene

c) Were later suspended from duty

d) Worked alone

Sue

In dealing with Time 1 Question 5, in which students were faced with an unknown and difficult word hélitreuillées (helicoptered), Sue seemed to demonstrate the practice identified in Field (2004: 372), whereby listeners try to match a heard item “very approximately, to a known one". In Sue's case the multiple choice options seem to have prompted this attempt at a match: thus she claimed to hear the word for yesterday (hier) as air, and elaborated from this to helicopter. She formed an uncertain hypothesis about this which she checked by listening again to the whole passage. However, after this re-listening, she acknowledged lack of comprehension: I hardly heard 'from the air'. Notably, however, she did not act upon this comprehension monitoring with any positive strategy and just gave up, explaining: I'm going to just 
leave it, because that one is hard. Nor did she seem to apply any schematic knowledge to infer what might be a likely answer in the context.

At Time 2, Sue's response to Question 4 was similarly characterised by uncertainty and a failure to complement comprehension monitoring with other strategies. Deduction based in negative evidence was also employed, as with earlier questions: $I$ didn't hear anything about working alone or being suspended. Although by Time 2 she did seem better able to identify chunks of language, and to integrate information from various parts of the passage (although they said quite a few people died but they didn't say no one lived), the focus on what was not heard is still notable. Likewise, although Sue correctly identified that bénévoles meant volunteers, she was uncertain about this interpretation, an uncertainty which she did not attempt to eradicate by further monitoring or seeking of additional information: I'm guessing it was that [...] I'm not sure.

Alan

For Alan, Time 1 Question 5 posed more difficulties than any other across the two passages. He was the only student who seemed able to identify hélitreuillées as the item central to comprehension of the phrase and to be able to reproduce it vocally. Indeed, vocalisation was a strategy he employed frequently at both time points. Nevertheless, after acknowledging that he did not know the word and frequent replaying of the relevant sections, he seemed unable to deal with a breakdown in linguistic knowledge or to apply top-down strategies such as inferencing from context to interpret the phrase. Thus he commented: I'm not gonna guess, cos I'd be stupid.... 
The ability to recognise almost instantly what he heard (on which at Time 1 Alan seemed almost to over-rely) was readily apparent at Time 2. Thus for Question 4 he explained:

Alan: Ah...B, four, were helped by the people at the scene.

I: How do you know?

Alan: It just said. ... 'bénévoles', 'de la place', or something like that.

\section{Pair E}

\begin{tabular}{|c|c|}
\hline Time 1 & Time 2 \\
\hline $\begin{array}{l}500 \text { personnes ont dî être hélitreuillées } \\
\text { hier, et ce matin deux villages sont } \\
\text { encore totalement isolés. Ainsi donc } \\
\text { dans cette région qui a connu l'horreur, à } \\
\text { quelques kilomètres de ceux qui ont déjà } \\
\text { recommencé à vivre, il reste donc des } \\
\text { centaines de personnes en grande } \\
\text { difficulté. }\end{array}$ & $\begin{array}{l}\text { Une cordée d'alpinistes britanniques } \\
\text { s'est décrochée et, en tombant dans le } \\
\text { vide, elle a bousculé les cordées situées } \\
\text { plus bas, qui sont tombées à leur tour, } \\
\text { les unes après les autres. Personne n'a } \\
\text { pu empêcher la chute, dans un } \\
\text { enchevêtrement de cordes mêlées, de } \\
\text { sacs et de crampons. }\end{array}$ \\
\hline 6. In the Aude department: & 2. The incident: \\
\hline a) Only a small area was affected & a) Could have been prevented easily \\
\hline $\begin{array}{l}\text { b) Life is getting back to normal for } \\
\text { everyone }\end{array}$ & b) Involved a series of tragic events \\
\hline $\begin{array}{l}\text { c) A section of the population is still in } \\
\underline{\text { danger }}\end{array}$ & c) Left the area completely deserted \\
\hline $\begin{array}{l}\text { d) The whole area was completely cut } \\
\text { off }\end{array}$ & d) Happened at the foot of the tower \\
\hline
\end{tabular}

Sue

These questions were probably the most difficult of those posed, requiring the integration of several pieces of information and a degree of interpretation, particularly at 
Time 2 where there was no straightforward lexical match between passage and options. Sue, at Time 1, incorrectly chose option a) and explained that this had been an educated guess based on believing she had heard isolated lexical items - petit village (not in the text) and un kilomètre. These were then elaborated upon to arrive at the conclusion that it's only a small area (also ignoring contradictory evidence from des centaines de personnes, hundreds of people). In spite of almost correctly interpreting the final lines of the passage as people are still having difficulties, Sue again applied negative deduction to confirm her hypothesis, perhaps expecting an exact lexical match: They didn't say anything about people being in danger. So I guess it's what I was left with. This one or that one.

Sue's Time 2 strategies were similar to those just outlined, although she seemed even more hampered by identification of only a limited amount of language, elaborated upon to arrive at a hesitant answer. Thus she explained that she chose a series of tragic events because:

Something that made me think it could be that, although.......although I can't remember what it was, something like 'cruel' something....I have a feeling it was that one but I am not sure.

Alan

At Time 1, Alan again correctly identified, seemingly automatically, a large chunk of language which he was able to recognise as a paraphrase of the correct option: Six I chose 'c' because he said only a small amount of people are still in danger.

At Time 2, he seemed less confident about what he heard but did hear the phrase cordes mêlées (tangled ropes) and vocalised it (the only student to do so for this phrase). 
He then elaborated on this to recognise that the tangle of ropes was part of the outcome of the series of tragic events, but at the same time questioning his interpretation and evaluating whether the other options were possible given the rest of what he had understood:

Une corde mêlée (sic). That's like, isn't that like a series of tragic events? Or something like that because 'mêle' isn't that just a load of things happening [...] I have read the other ones but I am not really sure (...) what they have in connection so...

\section{Discussion and Conclusions}

Two main themes emerge from the foregoing analysis. First, there are strategy differences between Alan, a high scorer in the listening proficiency test, and Sue, a low scorer on the same test, at both time points. Sue's strategy use consisted largely of prediction of lexis, writing visual prompts and selective attention, which for her meant listening out for particular words. Comprehension monitoring, i.e. registering whether one has or has not understood, was rarely followed by remedial strategies. Alan, by contrast, seemed to be willing to acknowledge the provisional nature of his interpretations when he was in doubt. He double-checked and questioned his interpretations, thus employing a number of metacognitive strategies. When not in doubt, he displayed an impressive ability to identify the key information. This may be a form of selective attention but it differs from Sue's use of the strategy in that it occurs once overall understanding, at phrase and passage level has occurred, and not prior to listening. It also seemed to have been automatised, as Alan almost never spoke of 'listening out' for items or key information. This echoes Peters' (1999) claim that 
selective attention becomes automatised with time. Alan also frequently used vocalisation, reproducing words or phrases he had heard. The fact that Sue used strategies such as prediction and selective attention which are normally associated with 'effective' listening (e.g. Vandergrift, 2003) does not mean that these strategies are in themselves unhelpful - rather that any strategy used needs to be used well and appropriately for it to be useful (Vann and Abraham, 1990). It also challenges a research approach that involves simply counting the presence or absence of certain strategies, and then trying to establish a cause-effect relationship between strategy use and listening performance.

Second, both students remained fairly consistent in their strategy use over the six month period. This is particular true of Sue's use of prediction, visual prompts and selective attention. While there is also some evidence in Sue of an incipient movement from 'a focus on words' at Time 1 to 'a focus on words and larger chunks' at Time 2, this movement (in principle, a very good one) seemed insufficient to help her deal with her listening problems satisfactorily. Arguably this is because at Time 2 she was still unable to apply potentially supporting strategies such as comprehension monitoring followed by strategies for checking, and instead continued to rely on negative deduction.

Possible limitations to the study include the case study approach adopted, looking at two students only. We would argue however, like Vann and Abraham (1990), that such an approach is necessary in order to explore how strategies are used, rather than which ones and how many or often. Additionally, we are aware of the fact that any discussion of strategies is necessarily linked with what gave rise to the uses of these strategies, i.e. the task set. This is a serious issue for researchers into listening strategy 
use and one that is very often overlooked. Again, we would argue that a case study approach facilitates a consideration of strategies within the context of a particular task. In addition, we have tried to address the connection between task and strategies by presenting the demands made by different aspects of the tasks and discussing how students dealt with similar problems across time in terms of their strategy use. Thus, although it might be argued that Sue's largely 'word level' approach to the task was partly attributable to the rewinding facility and to the choice of multiple choice questions, the fact that Alan did not share her approach suggests that this was not necessarily the case.

Overall, the study indicates that strategy use is highly individualised and that whatever strategies listeners use, they need to know how to use them effectively and appropriately to deal with task demands. The fact that Sue used strategies often associated with 'good' listeners underlines this point and challenges the notion that weaker learners can be helped by teaching them the strategies that deliver results for 'good' listeners. Rather, we would argue for a form of strategy instruction in which students are made aware of a wide range of strategies, but are encouraged to select and evaluate their use, so that they can learn to use whatever strategies they find helpful in a more efficient manner. The individual nature of strategy use displayed by the two participants also suggests a role for a mode of instruction that begins with an analysis of current strategy use (in terms of how strategies are used rather than which ones or how often) and which includes individual feedback from the teacher on how well strategies are being employed. The fact that Alan had apparently become a 'strategic' listener without instruction does not negate this argument as he did not always use strategies 
effectively (Question 5, Time 1). Teachers will surely wish to help all students to use their knowledge and skills to the best possible effect.

Ultimately, however, teachers require knowledge about the role of strategies and strategy development in order to assist their students in this process. It is hoped that this study will contribute to this knowledge development, as well as to strategy theory, by illustrating the importance of examining how strategies are used, and in the context of specific tasks.

Notes:

1. Pseudonyms have been used to preserve anonymity.

2. Unknown vocabulary was defined as items that did not appear in the examination syllabus that the participants had followed for the GCSE. 


\section{References}

Alderson J.C., Banerjee, J., 2002. Language testing and assessment (Part 2). Language Teaching 35, 79-113.

Authentik en français, 2001. Mars/avril. Trinity College, Dublin.

Bacon, S.M., 1992. The relationship between gender, comprehension, processing strategies, and cognitive and affective response in foreign language listening. The Modern Language Journal 76 (ii), 160-178)

Berkemeyer, V. C., 1989. Recall protocol data: some classroom implications. Die Unterrichtspraxis 21(3), 131-137.

Chamot, A.U., 2004 Issues in language learning strategy research and teaching. Electronic Journal of Foreign Language Teaching 1(1), 14-26. Retrieved 9/11, 2007, from http://eflt.nus.edu.sg/v1n12004/chamot.pdf

Corless, F., Corless, H., Gaskell, R., 1990. Signes du Temps: Vécu. Hodder and Stoughton, London.

Field, J., 2004. An insight into listeners' problems: too much bottom-up or too much top-down? System 32, 363-377. 
Laviosa, F., 2000. The listening comprehension processes and strategies of learners of Italian: a case study. Rassegna Italiana di Linguistica Applicata 2, 129-159.

Macaro, E., Graham, S., Vanderplank, R., 2007 . A review of listening strategies: focus on sources of knowledge and on success. In: Cohen, A.D., Macaro, E. (Eds.), Language Learner Strategies: 30 Years of Research and Practice. Oxford University Press, Oxford, pp. 165-185.

McGruddy, R., 1995. The effect of listening comprehension strategy training with advanced level ESL students. Unpublished PhD dissertation, Georgetown University, Washington, DC, USA.

O’Malley, J., Chamot, A.U., 1990. Learning Strategies in Second Language Acquisition. Cambridge University Press, Cambridge.

Ozeki, N., 2000. Listening strategy instruction for female EFL college students in Japan. Unpublished PhD dissertation, Indiana University of Pennsylvania, The Graduate School and Research Department of English.

Peters, M., 1999. Les stratégies de compréhension auditive chez des élèves du Bain Linguistique en français langue seconde. Unpublished $\mathrm{PhD}$ dissertation, Ottawa University, Canada. 
Santos, D., Graham, S., Vanderplank, R., under review. Second language listening strategy research: methodological challenges and perspectives.

Seliger, H.W., 1983. The language learner as linguist: of metaphors and realities. Applied Linguistics 4 (3), 179-191.

Seo, K., 2000. Intervening in tertiary students' strategic listening in Japanese as a foreign language. Unpublished PhD dissertation, Griffith University, Australia.

Vandergrift, L., 1997. The comprehension strategies of second language (French) listeners: a descriptive study. Foreign Language Annals 30 (3), 387-409.

Vandergrift, L., 1998. Successful and less successful listeners in French: what are the differences? The French Review 71 (3), 370-395.

Vandergrift, L., 2003. Orchestrating strategy use: toward a model of the skilled second language listener. Language Learning 53(3), 463-496.

Vann, R.J., Abraham, R.G., 1990. Strategies of unsuccessful language learners. TESOL Quarterly 24(2), 177-198.

Vogely, A., 1995. Perceived strategy use during performance on three authentic listening tasks. The Modern Language Journal 79 (1), 41-56. 
White, C., Schramm, K., Chamot, A.U., 2007. Research methodology in language

learner strategies. In: Cohen, A.D., Macaro, E. (Eds.), Language Learner Strategies: 30 Years of Research and Practice. Oxford University Press, Oxford, pp. 93-116. 
Figure 1. Taxonomy of listening strategies used for coding. NB: only the strategies

discussed in the present article are included, for reasons of space.

\begin{tabular}{|c|c|c|}
\hline \multicolumn{2}{|c|}{ Strategy name } & Definition \\
\hline \multicolumn{2}{|c|}{ Prediction lexis } & Activates L2 lexical knowledge prior to listening \\
\hline \multicolumn{2}{|c|}{ Prediction possible answers } & $\begin{array}{l}\text { Prior to listening, predicts what might be possible } \\
\text { answers }\end{array}$ \\
\hline \multicolumn{2}{|c|}{ Match lexis heard to lexis in options } & $\begin{array}{l}\text { Hears item in text then chooses option containing } \\
\text { that item }\end{array}$ \\
\hline \multicolumn{2}{|l|}{ Elaboration } & $\begin{array}{l}\text { Builds up meaning from one or two items heard, } \\
\text { using prior/world knowledge to fill in gaps }\end{array}$ \\
\hline \multicolumn{2}{|c|}{ Hypothesis formation } & Suggests a possible answer/interpretation \\
\hline \multicolumn{2}{|c|}{ Selective attention } & Decides to listen out for certain items \\
\hline \multirow[t]{4}{*}{ Monitoring: } & Comprehension monitoring & $\begin{array}{l}\text { Establishes whether one has or has not } \\
\text { understood }\end{array}$ \\
\hline & $\begin{array}{l}\text { Monitoring against the } \\
\text { question }\end{array}$ & $\begin{array}{l}\text { Checks to see if one's interpretation makes sense } \\
\text { in the light of the comprehension question posed }\end{array}$ \\
\hline & Hypothesis monitoring & $\begin{array}{l}\text { Checks whether hypothesis is verified or } \\
\text { contradicted by text or subsequent information }\end{array}$ \\
\hline & Double-check monitoring & $\begin{array}{l}\text { Tracks, across the task, previously undertaken } \\
\text { acts or possibilities considered* }\end{array}$ \\
\hline \multicolumn{2}{|l|}{ Integration } & $\begin{array}{l}\text { Draws together two or more pieces of information } \\
\text { to reach a conclusion }\end{array}$ \\
\hline \multicolumn{2}{|l|}{ Vocalisation } & Reproduces French heard on tape, orally \\
\hline \multicolumn{2}{|c|}{ Visual/written prompts } & Writes down 'key' words next to options \\
\hline \multicolumn{2}{|c|}{ Negative deduction } & Deduction based on what is not heard \\
\hline \multicolumn{2}{|c|}{ Self-questioning } & $\begin{array}{l}\text { Interrogates oneself about possible answers or the } \\
\text { best way to proceed }\end{array}$ \\
\hline
\end{tabular}

* from Vandergrift (2003: 494). 
Table 1 Pairings of questions (Time 1 and Time 2)

\begin{tabular}{|l|l|l|}
\hline & Question pairs & $\begin{array}{l}\text { Potential problems posed/ } \\
\text { Question type/ } \\
\text { Demands }\end{array}$ \\
\hline Pair A & $\begin{array}{l}\text { Time 1 Question 1; } \\
\text { Time 2 Question 1 }\end{array}$ & $\begin{array}{l}\text { Aimed at students' global understanding of } \\
\text { the passage. However, clues were available } \\
\text { in the opening lines and later sections of the } \\
\text { passages confirmed the disaster' element of } \\
\text { the passage, as did the options. }\end{array}$ \\
\hline Pair B & $\begin{array}{l}\text { Time 1 Question 3*; } \\
\text { Time 2 Question 3 }\end{array}$ & $\begin{array}{l}\text { Required fairly local understanding at phrase } \\
\text { and individual item of lexis level, of time } \\
\text { phrases and numbers. Several time phrases } \\
\text { or numbers occurred around the phrase } \\
\text { containing the key information (as well as in } \\
\text { the options). }\end{array}$ \\
\hline Pair C & $\begin{array}{l}\text { Time 1 Question 4; } \\
\text { Time 2 Question 5 }\end{array}$ & $\begin{array}{l}\text { Required understanding at phrase level - of } \\
\text { individual numbers, but also the nouns they } \\
\text { related to. Again, other numbers were } \\
\text { present in the passage as distracters. For } \\
\text { Time 2, the information was presented at the } \\
\text { start of the passage. }\end{array}$ \\
\hline Pair D & $\begin{array}{l}\text { Time 1 Question 5; } \\
\text { Time 2 Question 4 }\end{array}$ & $\begin{array}{l}\text { Required understanding at phrase level. One } \\
\text { difficult item held the key to the phrase, } \\
\text { particularly at Time 1. However, it was } \\
\text { possible to infer the meaning of this item } \\
\text { from the overall context of the passage, } \\
\text { although distracters were also plausible } \\
\text { within this context. }\end{array}$ \\
\hline Time 2 Question 2 & $\begin{array}{l}\text { Required the understanding and integration of } \\
\text { several pieces of information. Little direct } \\
\text { correspondence between lexical items in the } \\
\text { text and the options. }\end{array}$ \\
\hline
\end{tabular}

* There was no Time 2 Question that directly corresponded to Question 2 of the Time 1 passage, although it was similar to both sets of Question 3. 
* Corresponding author. Tel.: +44 (0) 118378 8838; fax: +44 (0) 1183788834

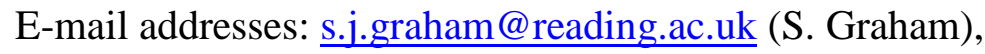

d.m.d.santos@ reading.ac.uk (D. Santos), robert.vanderplank@language-

centre.oxford.ac.uk (R. Vanderplank).

${ }^{1}$ Tel: +44 (0)118 378 7457; fax: +44 (0) 1189753365

${ }^{2}$ Tel: +44 (0) 1865 283360; fax: +44 (0) 1865283366 